\title{
COMPARISONS OF WAVE OVERTOPPING DISCHARGES AND DAMAGES OF THE NTOU VERTICAL SEAWALL DUE TO TWO SIMILAR SUPER TYPHOONS ON KEELUNG COAST OF TAIWAN
}

\author{
Da-Wei Chen ${ }^{1}$ Shiaw-Yih Tzang ${ }^{2}$ Shan-Hwei Ou ${ }^{3}$
}

\begin{abstract}
In this study, SWAN model was first applied to obtain wave conditions during Typhoon Herb (1996) and Krosa (2007). Then the results were used for estimating the wave overtopping discharge with existing empirical formulae selected from EurOtop manual. In the EurOtop formulae, calculations of overtopping discharges can be improved by adapting average wave period $\left(T_{m-1,0}\right)$ for swell conditions. The results show that the peak overtopping discharges during Typhoon Herb (1996) are larger than those during Typhoon Krosa (2007) at the two selected sites. In addition, the water depth at toe of eastern NTOU seawalls (NTOU 2) are shallower than that at northern NTOU seawall (NTOU 1) so that the discharges at NTOU 1 are larger than those at NTOU 2. The calculations show that the peak wave overtopping discharges during both typhoons are greater than the criteria for damages on back slope of seawalls, which agrees with the NTOU seawall failure event during Typhoon Herb. The predicted failure does not again happen to NTOU seawall during Typhoon Krosa implying the effective reduction in overtopping discharges by lifting up $1 \mathrm{~m}$ of the crest after rebuilding the previously damaged seawall.
\end{abstract}

Keywords: wave overtopping; vertical seawall; structure damages; typhoon

\section{INTRODUCTION}

Taiwan is located on the edges of western Pacific Ocean so that its coastal areas are usually threatened by violent wave during typhoon periods. In recent years, the seawalls of National Taiwan Ocean University (NTOU) in Keelung of northeastern Taiwan have frequently suffered consecutive damages due to typhoon waves. In 1996, a super Typhoon Herb struck the vertical NTOU seawalls of the reclaimed campus causing partial damages on the parapet, as shown in Fig. 1 (a). According to Tsai et al. (2006), the damages were primarily caused by significant wave overtopping due to extreme high water levels consisting of high spring tide and storm surge and associated large waves. Tzang et al. (2009) have further calculated the overtopping discharges with existing empirical formulae and shown that during certain periods the discharges could be greater than the design criteria according to Coastal Engineering Manual (CEM, 2002).

Later, the NTOU seawalls had been consecutively damaged by typhoons in the same and the following year, i.e. Typhoon Zane(1996), Typhoon Winnie(1997) (Tzang and Hsiao, 1999). The seawalls were then rebuilt in 1998 by mainly lifting up $1 \mathrm{~m}$ of the crest heights. However, in 2007, another super Typhoon Krosa with similar path of Typhoon Herb (see Fig. 2) struck the rebuilt seawalls but caused only damages on the concrete coverings of the drainage ditches right behind the parapet. From a similar previous case, Tzang et al. (2003) reported that typhoon waves might result in intense water hammer drainage in the channels by breaking on the drainage outlet on vertical faces of the seawall. The strong upward jets could subsequently break the coverings and push away broken pieces. Then the following overtopping water could have pounded on and displace those broken concrete pieces further, as shown in Fig. 1 (b).

In order to understand the different effects of wave overtopping discharges over the lifted-up crest elevation of the rebuilt seawalls during Typhoon Krosa, it is aimed in this study at carrying out calculations and comparisons with existing empirical formulae and those of EurOtop Manual.

1 Department of Harbor and River Engineering, National Taiwan Ocean University, 2 Pei-Ning Road, Keelung, Taiwan, 202, R.O.C.

2 Department of Harbor and River Engineering, National Taiwan Ocean University, 2 Pei-Ning Road, Keelung, Taiwan, 202, R.O.C.

${ }^{3}$ Department of Environmental Resources Management, Tajen University, 20 Weisin Road, Sin-er Village, Yanpu Township, Pingtung, Taiwan, 907, R.O.C. 


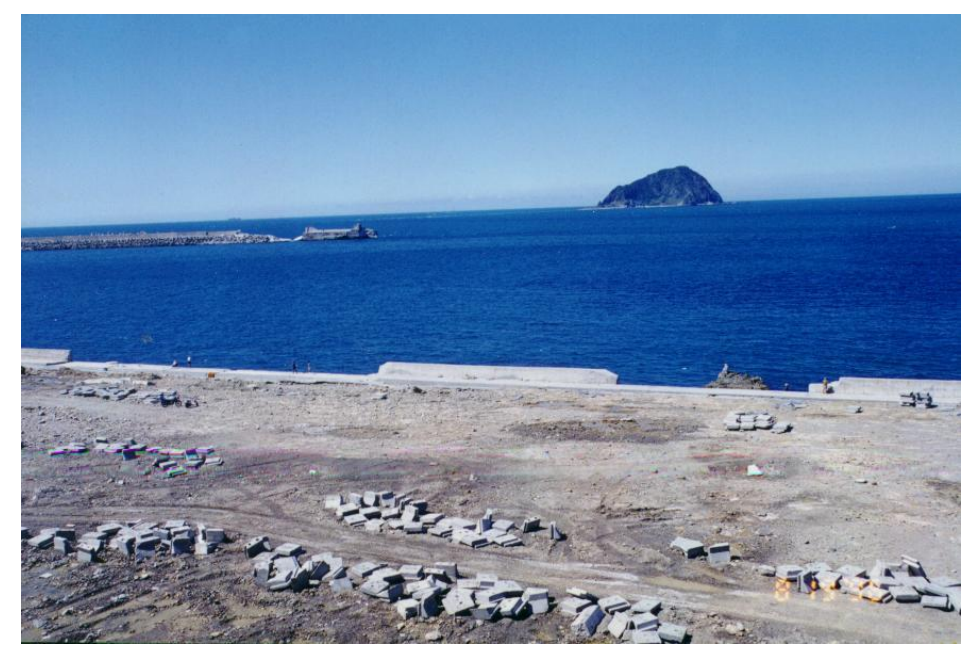

(a) Typhoon Herb (1996)

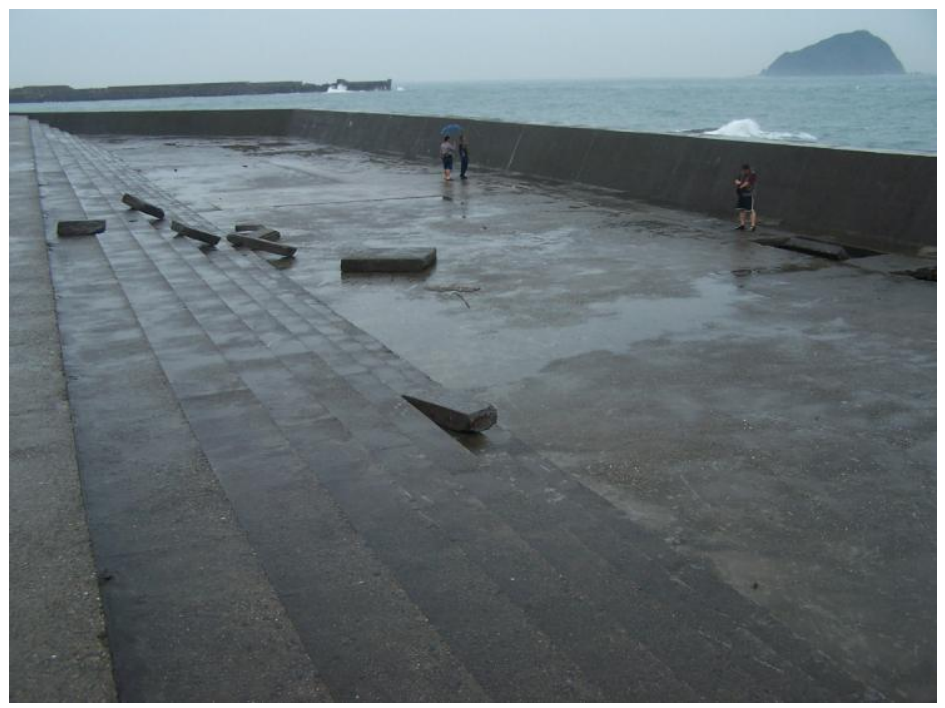

(b) Typhoon Krosa (2007)

Figure 1. The damages on NTOU seawall.

\section{OVERTOPPING FORMULAE}

In recent years, many findings have been obtained from investigations on overtopping flows over coastal structures in several large program projects of European Union. As summarized in Coastal Engineering Manual, mean overtopping discharges are more widely adopted, though the local overtopping discharge (in $\mathrm{m}^{3} / \mathrm{s} / \mathrm{m}$ ) from a single wave can sometimes be 100 times larger during the storm peaks (CEM, 2002).

\section{Empirical Formulae}

The mean overtopping discharges are defined as the average over 500 or 1000 random waves from the model tests (Bruce et al., 2001). For quite a longtime, Goda's formulae (Goda, 1985) have been the commonly adopted method, and calculations can be directly obtained from design diagrams for cases of vertical wall and block mound seawalls. But a disadvantage of this method is that interpolation of the diagrams by the user is required. To overcome the disadvantages, some researchers had further extended the work of Goda to take into accounts of bottom slopes, wave steepness and sloping breakwaters, e.g. Herbert (1993); Jensen and Sorensen (1979).

Franco et al (1994) studied wave overtopping over various caisson breakwaters, especially in deep water by unbroken waves. Their model is represented by dimensionless parameters $Q^{*}$ for discharges and $\mathrm{R}^{*}$ for freeboard from specific structure geometry. Based on additional model tests, Allsop et al. (1995) found that formulae of Fasnco et al. (1994) would underestimate for larger 
values of $R_{c} / H_{s}$, where $R_{c}$ is the freeboard height and $H_{s}$ the significant wave height. They proposed that this parameter can be used in deep and shallow water. Later, Besley et al. (1998) extended formulae by Allsop et al. (1995) with another parameter $\mathrm{d}^{*}$ to deal with influences of a berm in front of a vertical wall. Franco et al. (1999) had also revised their previous version by taking in new parameters from the reanalysis of the data used by Franco et al. (1994), and with additional results from 3D model tests.

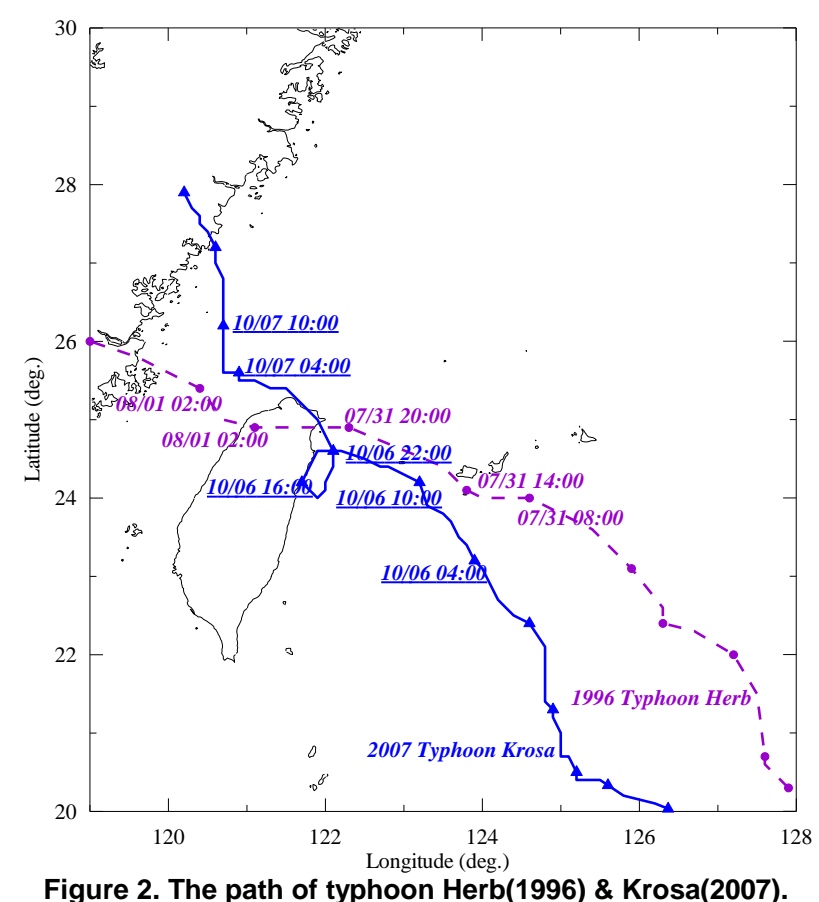

\section{EurOtop}

According to EurOtop (2007), the manual is developed from three manuals: the Environment Agency Manual on Overtopping (U.K.), the TAW Technical Report on Wave run-up and wave overtopping at dikes (Netherlands), and the German Die Küste EAK (2002). The new combined manual has extended and developed the parts of those manuals to discuss wave run-up and overtopping for coastal structure of various types, including seawall, flood embankment, breakwater, and shoreline structure.

In EurOtop (2007), the predicting formulae are typically applicable for three types of seawalls: plain vertical seawall, vertical composite wall, and vertical battered wall. For safety assessment, the predicted discharges are based on either deterministic design or probabilistic design. The probabilistic design takes into account the effects of uncertainties from all parameters including wind, wave and surge statistics. It is noted that the spectral period $\left(T_{m-1,0}=m_{-1} / m_{0}\right)$ is adopted as the parameter of wave period. In general, the relationship between the spectral period $\left(T_{m-1,0}\right)$ and the commonly adopted peak period $\left(T_{p}\right)$ are $T_{p}=1.1 T_{m-1,0}$. Since plain vertical seawall formulae of EurOtop (2007) are better formulated, the overtopping discharges are simulated by plain vertical formulae in this paper.

\section{WAVE SIMULATION}

To simulate the typhoon waves, the work presented herein adopt primarily the SWAN model of version 40.72. The far-field computational domain of the nested grids, as shown in Fig. 3 (a), covers the range from $10^{\circ}$ to $34^{\circ} \mathrm{N}$ and $110^{\circ}$ to $140^{\circ} \mathrm{E}$. The area is selected to include the affecting processes of a typhoon. The near-field computation domains cover the area in northeastern Taiwan including Keelung, which are also detailed in Fig. 3 (b). It is seen in Table 3 that for far-field wave simulation the grid spacing is $20 \mathrm{~km}$ and the computational time step is 15 
min. In the near-field nested domains grid sizes of $5 \mathrm{~km}, 800 \mathrm{~m}$ and $28 \mathrm{~m}$ are for layers 2, 3 and 4, respectively.

In this study, the SWAN model has been driven by $10 \mathrm{~m}$ wind field above sea water level obtained from the Cross-Calibrated Multi-Platform (CCMP). They are the observational data per 6 hr with grid accuracy of $0.25^{\circ}$ by NASA. In addition, in order to improve high-resolution in $1 \mathrm{hr}$ for computational domains when typhoons approach to Taiwan, the wind field model of CCMP was coupled with RVM (Rankin-Vortex Model) by interpolations on each computational grid.

\begin{tabular}{|c|c|c|c|c|c|}
\hline Formulae & $\begin{array}{l}\text { Types } \\
\text { / wave }\end{array}$ & Hydraulics conditions & model & $\begin{array}{c}\text { Dimensionless } \\
\text { Freeboard R }\end{array}$ & $\begin{array}{c}\text { Dimensionless } \\
\text { discharge Q }\end{array}$ \\
\hline $\begin{array}{l}\text { Allsop et al. } \\
\text { (1995) }\end{array}$ & $\begin{array}{l}\text { Vertical } \\
\text { (unbroken) } \\
\text { Vertical } \\
\text { (broken) }\end{array}$ & $\begin{array}{l}\text { (1) } 0.03<\mathrm{R}_{\mathrm{C}} / \mathrm{H}_{\mathrm{s}}<3.2, \\
\text { ignore water depth. } \\
\text { (including unbroken \& broken } \\
\text { waves) } \\
\left(2 \mathrm{~h}^{*} \leqq 0.3 \text {, for impacting waves }\right. \\
3 \mathrm{~h}^{*}>0.3 \text {, for reflecting waves }\end{array}$ & $\begin{array}{c}Q=\frac{q}{\sqrt{g H_{s}^{3}}} \\
Q=\frac{q}{\sqrt{g h^{3}}} \frac{1}{h^{* 2}}\end{array}$ & $\begin{array}{c}R=\frac{R_{c}}{H_{s}} \\
R=\frac{R_{c}}{H_{s}} \cdot h^{*}\end{array}$ & $\begin{array}{c}Q=a \exp (-b R) \\
Q=a R^{-b}\end{array}$ \\
\hline $\begin{array}{l}\text { Allsop et al. } \\
\left(\begin{array}{c}1995) \\
\& \\
\text { Besley et al. } \\
(1998)\end{array}\right.\end{array}$ & $\begin{array}{c}\text { Composite } \\
\text { (unbroken) } \\
\text { Composite } \\
\text { (broken) } \\
\text { Composite } \\
\text { (broken) }\end{array}$ & $\begin{array}{l}\text { (1) } d^{*}>0.3 \text { or } R_{c} / H_{s}<1.5 \\
\text { for unbroken waves } \\
\text { (2) } d^{*} \leqq 0.3 \text { or } R_{c} / H_{s}>1.5 \\
\text { for broken waves } \\
\text { (3) } d<0 \text {, structures with emergent } \\
\text { mound. }\end{array}$ & $\begin{array}{c}Q=\frac{q}{\sqrt{g H_{s}^{3}}} \\
Q=\frac{q}{\sqrt{g H_{s}^{3}}} \frac{1}{d^{* 2}} \\
Q=\frac{q}{\sqrt{g h^{3}}} \frac{1}{d^{42}}\end{array}$ & $\begin{array}{c}R=\frac{R_{c}}{H_{s}} \\
R=\frac{R_{c}}{H_{s}} d^{*} \\
R=\left(\frac{R_{c}}{H_{s}}\right)\left(\frac{d}{H_{s}}\right) \cdot d^{*}\end{array}$ & $\begin{array}{c}Q=a \exp (-b R) \\
Q=a \exp (-b R) \\
Q=a R^{-b}\end{array}$ \\
\hline
\end{tabular}

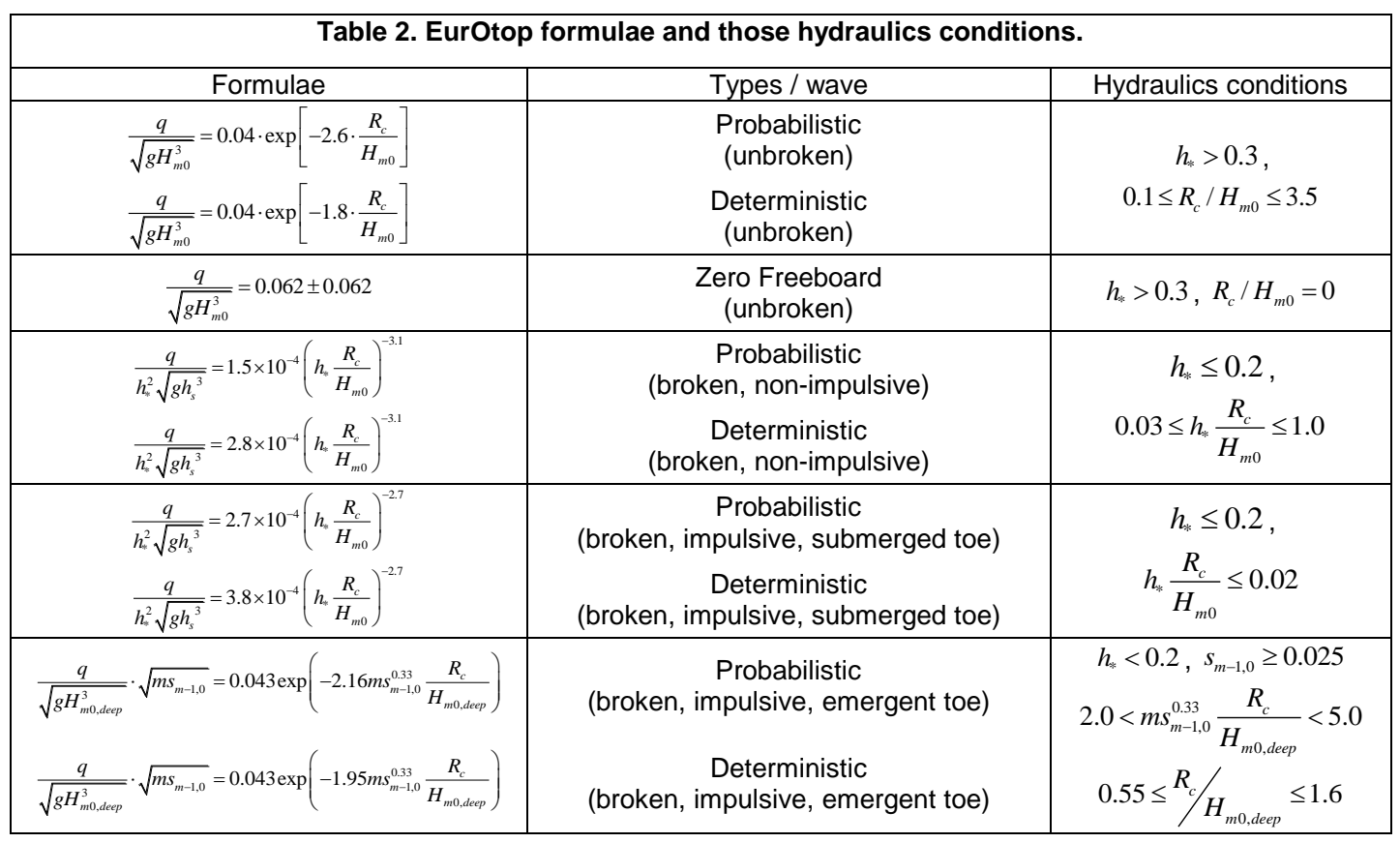

\begin{tabular}{|c|c|c|c|c|}
\hline $\begin{array}{l}\text { nested } \\
\text { grid }\end{array}$ & Data source & Filename & Resolution & $\begin{array}{l}\text { Geographic } \\
\text { resolution }\end{array}$ \\
\hline \multirow{3}{*}{$\begin{array}{l}\text { Layer } 1 \\
\text { Layer } 2 \\
\text { Layer } 3 \\
\text { Layer4 }\end{array}$} & National Oceanographic Data Center & ETOPO1 & \multirow{3}{*}{$\begin{array}{l}\triangle x=\triangle y=0.2^{\circ} \\
\triangle x=\triangle y=0.04^{\circ} \\
\triangle x=\triangle y=0.008^{\circ} \\
\triangle x=\triangle y=0.00025^{\circ}\end{array}$} & \multirow{3}{*}{$\begin{array}{l}\sim 20 \mathrm{~km} \\
\sim 5 \mathrm{~km} \\
\sim 800 \mathrm{~m} \\
\sim 28 \mathrm{~m}\end{array}$} \\
\hline & National Center of Ocean Research & TaiDBMV6 & & \\
\hline & \multicolumn{2}{|c|}{$\begin{array}{c}\text { Electronic Chart System } \\
\text { Measurement }\end{array}$} & & \\
\hline
\end{tabular}




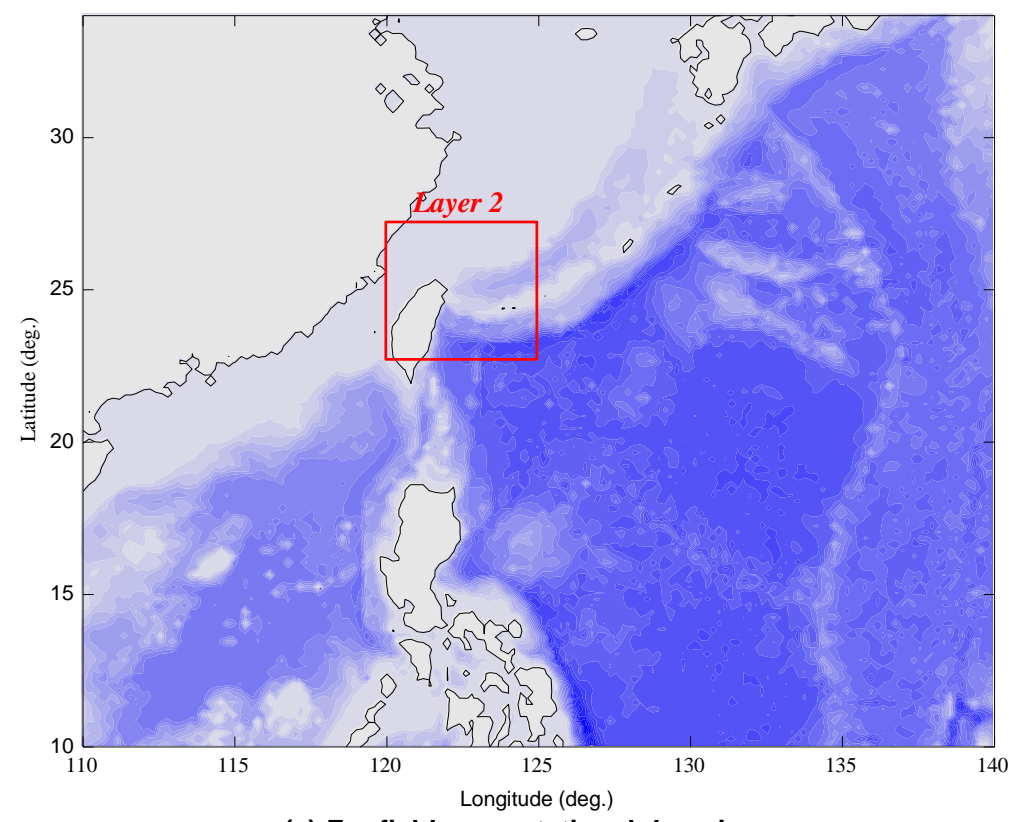

(a) Far-field computational domain

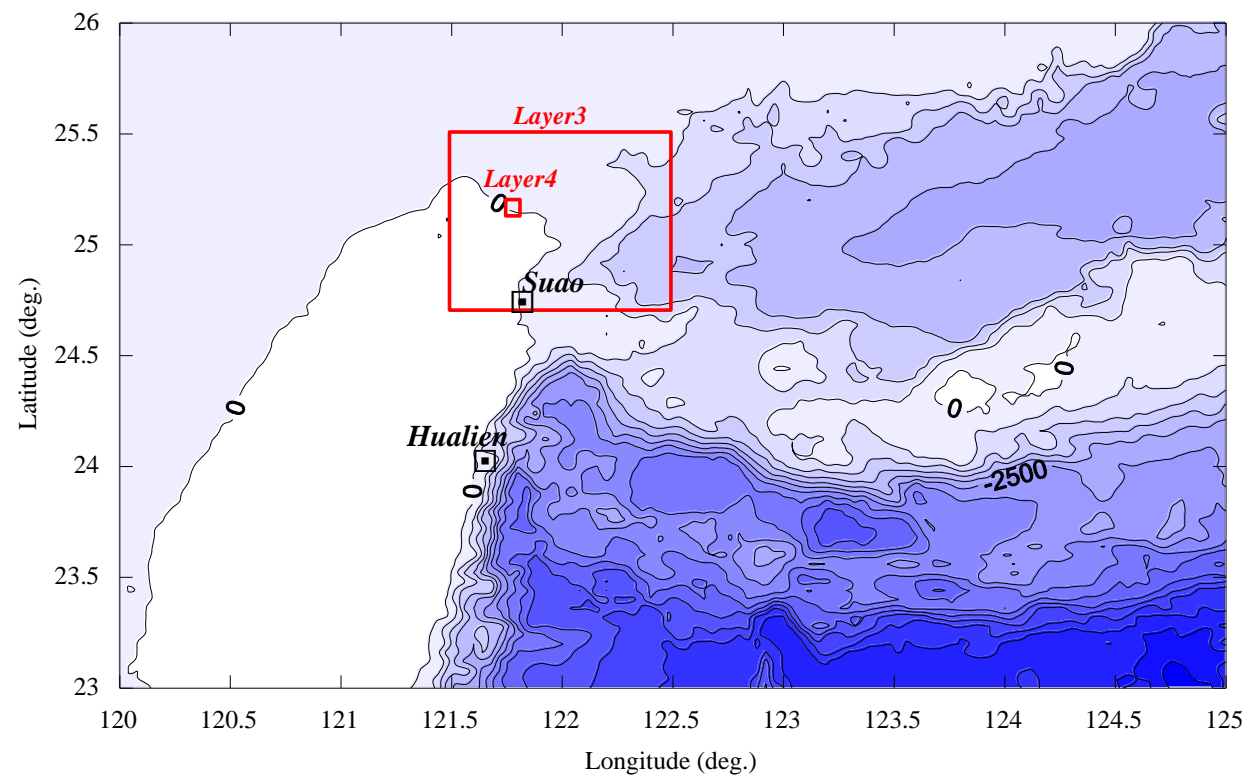

(b) near-field computation domains

Figure 3. Coastal topography of the nested domains.

\section{Model Validation}

Comparisons of the predicted wave heights and periods with field data measured at Hualien and Suao stations on the east coastal waters of Taiwan during Typhoon Herb (1996) and Krosa (2007) are shown in Fig. 4 (a) and 4 (b). The circles represent the measured data and the curve represents the predicted results. It can be seen from Fig. 4 (a), the measured maximum significant wave height $\left(H_{s}\right)$ of $7.6 m\left(T_{m}=13.3 s\right)$ occurred at 06:00 on July 31 during Typhoon Herb, while the simulated significant wave height of $4.3 \mathrm{~m}\left(T_{m}=10.2 \mathrm{~s}\right)$ occurred at 17:00 on July 31. In addition, in Fig. 4 (b), the measured maximum $H_{s}$ of $11.7 m\left(T_{m}=10.6 s\right)$ occurred at 14:00 on Oct. 6 during Typhoon Krosa, while the simulated maximum $H_{s}$ of $8.5 \mathrm{~m}\left(T_{m}=10.0 \mathrm{~s}\right)$ occurred at 13:00 on Oct. 6. Hence, the comparisons show that the simulated values of Typhoon Krosa agreed better with measured data on magnitude and occurrence time than the simulations of Typhoon 
Herb did. But agreements between the simulations and measured data through the whole time series for both typhoons are similar.
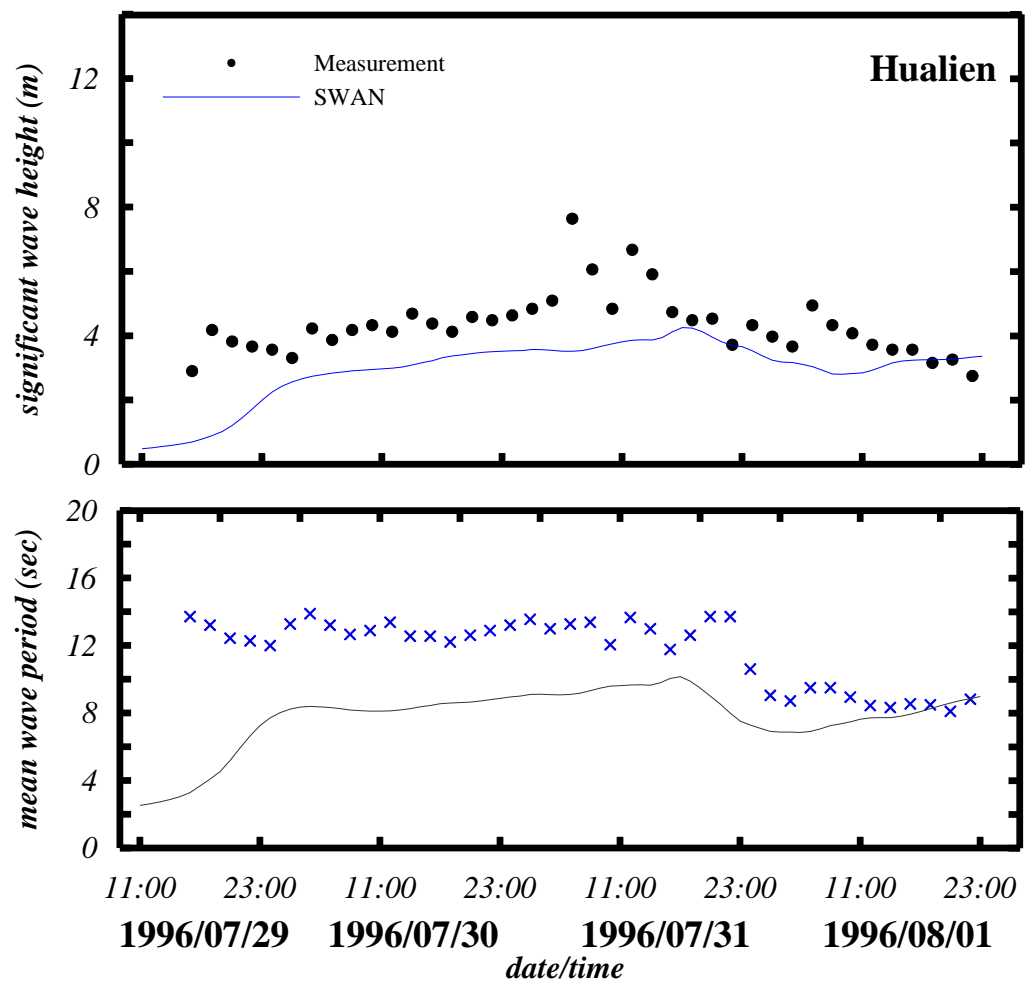

(a) Typhoon Herb
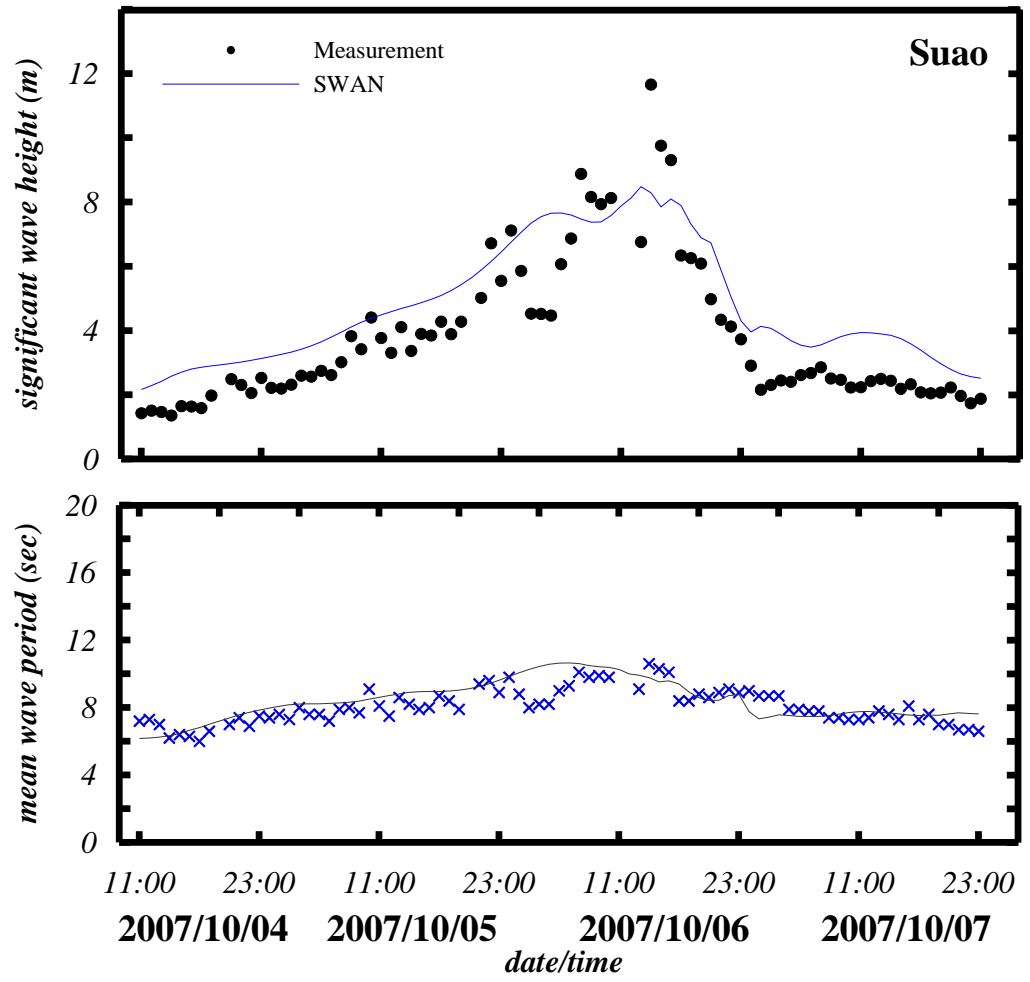

(b) Typhoon Krosa (2007)

Figure 4. Comparisons of significant wave heights and periods predicted by the SWAN wave model with measurements during the passage of Typhoon Herb \& Krosa. 


\section{Wave conditions}

The NTOU seawalls have suffered damages due to typhoon-induced waves for many times in the past, especially in eastern wall (NTOU 2) and northern wall (NTOU 1), as shown in Fig. 5. The static water depths at the two locations are $4 m$ (NTOU 1) and $3 m$ (NTOU 2), respectively. The simulations by SWAN model show that at the two sites of NTOU 1 and NTOU 2, maximum $H_{s}$ are $3.5 m(10.3 s)$ and $3.3 m(10.4 s)$ at 23:00 on July 31 during Typhoon Herb. The first peak $H_{s}$ are $3.6 \mathrm{~m}(10.6 \mathrm{~s})$ and $3.6 \mathrm{~m}(10.4 \mathrm{~s})$ at 16:00 on Oct. 6 while the second peak $H_{s}$ are $3.2 \mathrm{~m}(9.1$ $s)$ and $3.0 m(9.3 s)$ at 23:00 on Oct. 6 during Typhoon Krosa, as shown in Fig. 7 and 8. However, comparisons of the occurring times of maximum $H_{s}$ along typhoon path, the simulations of two locations during Typhoon Krosa show that the first peak values of $H_{s}$ were primarily due to nearly stationary typhoon moves offshore the eastern Taiwan (see Fig. 2). The second peak values of $H_{s}$ were induced by typhoon's low pressure center as it continued to pass over Keelung.

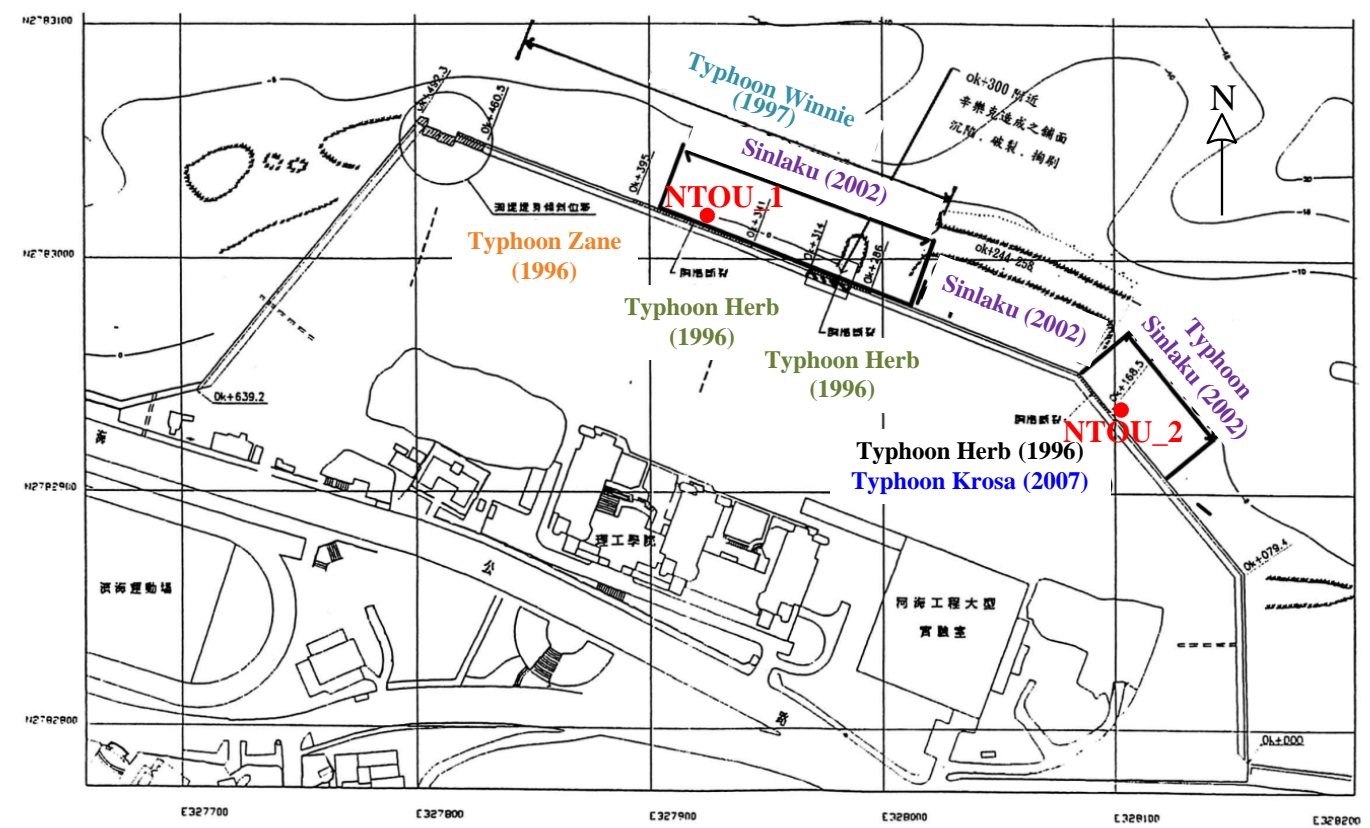

Figure 5. The sites of consecutive damages and predicted wave conditions by SWAN model.

\section{WAVE OVERTOPPING DISCHARGES}

\section{Parameters setting}

The NTOU seawall stood on rocky bottoms with an offshore slope of about 1:10. The seawall was originally designed as a vertical composite structure with a berm of 20-ton tetrapods. But the foundation quarry stones were only placed at sites with elevation under E.L. $-2.0 \mathrm{~m}$. The elevations of crown walls were E.L. $+6 m$ for original wall during Typhoon Herb and E.L. $+7 m$ for rebuilt wall during Typhoon Krosa, as shown in Fig. 6 (a) and 6 (b). In particular before the attack of Typhoon Herb in 1996, the seawalls had suffered from several typhoon attacks so that many of the berm tetrapods might have been dislocated to be more like a vertical wall structure. Thus, the overtopping flow discharges shall be calculated by selected empirical formulae for both cases. For the simulations, the water depths including typhoon surges were selected from the nearby tidal station in Port of Keelung.

To predict mean overtopping flow rates, most of the empirical formulae require wave conditions at toe and configuration parameters of coastal structures. For Goda's formulae, the equivalent deep-water wave heights and deep-water wave lengths are required to obtain overtopping discharges within certain water depths. In particular, some of the calculations need to 
be derived by interpolation from the diagrams. The hydraulic coefficients and associated parameters of the applied formulae are respectively listed in Table 1 and Table 2.

\section{Analysis}

Design of crest level for coastal structures generally takes into account allowable overtopping discharges. For embankment seawalls, the critical values of mean overtopping discharge are marked together with the predicted values. It can be seen in Fig. 7 and Fig. 8 that the predictions had one peak value during Typhoon Herb and two peak values during Typhoon Krosa. In addition, the overtopping discharges predicted by deterministic and probabilistic methods from EurOtop manual are also displayed in these two figures. Moreover, all the predictions by EurOtop manual have adopted average wave period $\left(T_{m-1,0}\right)$ for swell conditions.

Comparisons of the sea water level at two sites in two typhoons have shown that the peak value of $2.28 \mathrm{~m}$ during Typhoon Herb is larger than the peak value of $1.71 \mathrm{~m}$ during Typhoon Krosa. During Typhoon Herb, the peak water level occurred at 22:00 on July 31 while peak significant wave height occurred about 1 hour later as the typhoon approached, as shown in Fig. 7(a). On the contrary, the occurrence times during Typhoon Krosa for maximum values of important parameters are different from each other, as shown in Fig. 8(a).

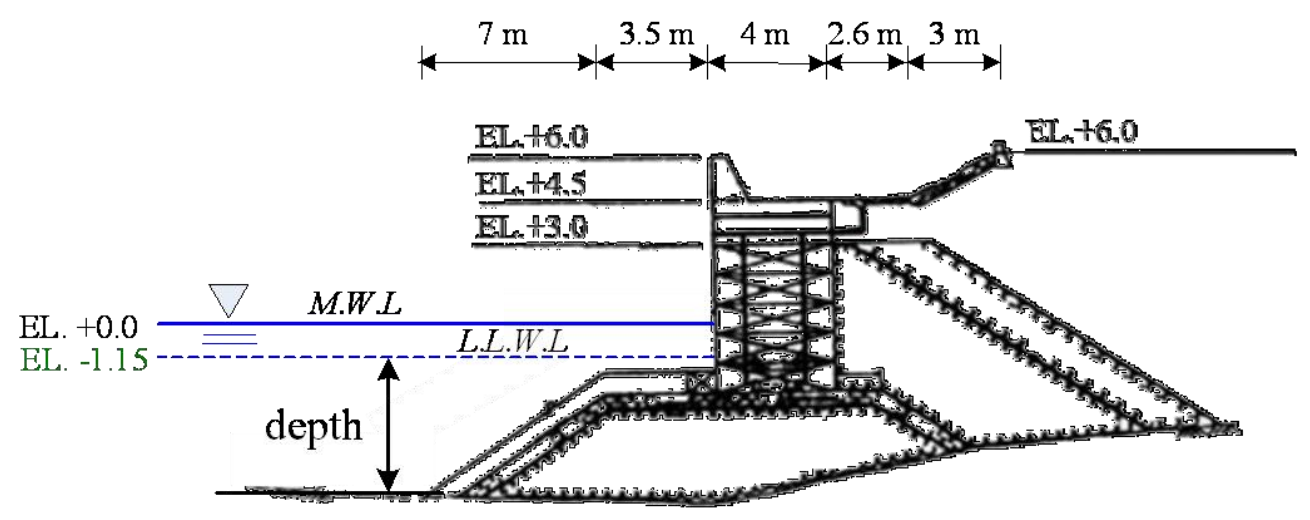

(a) Old wall

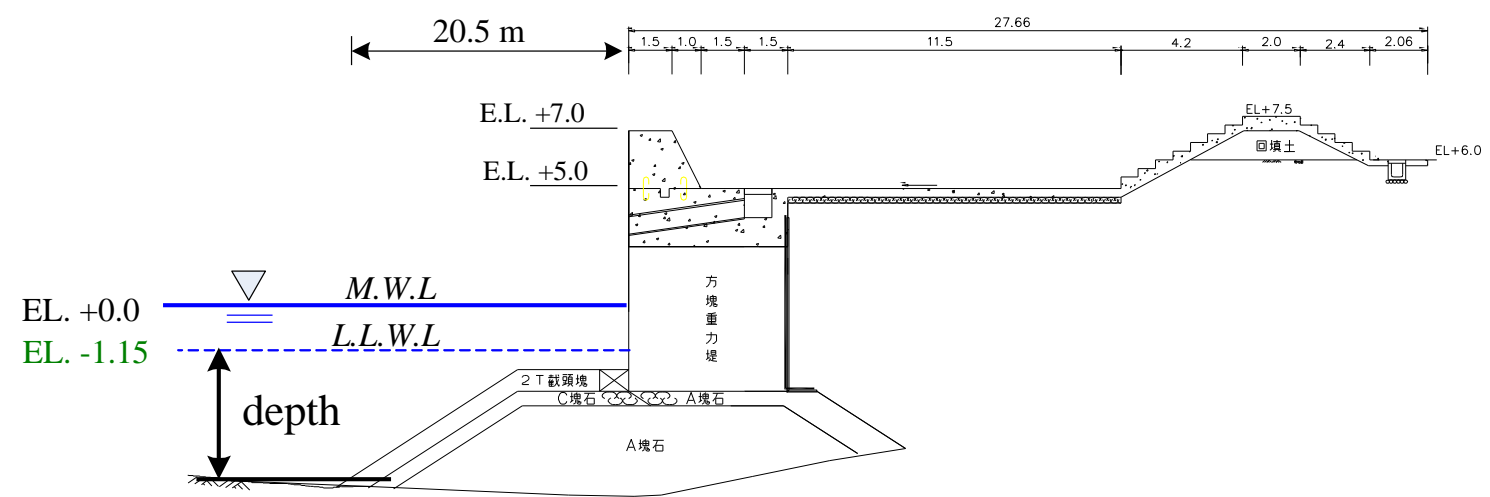

(b) New wall

Figure 6. NTOU seawall originally designed for new and old. 


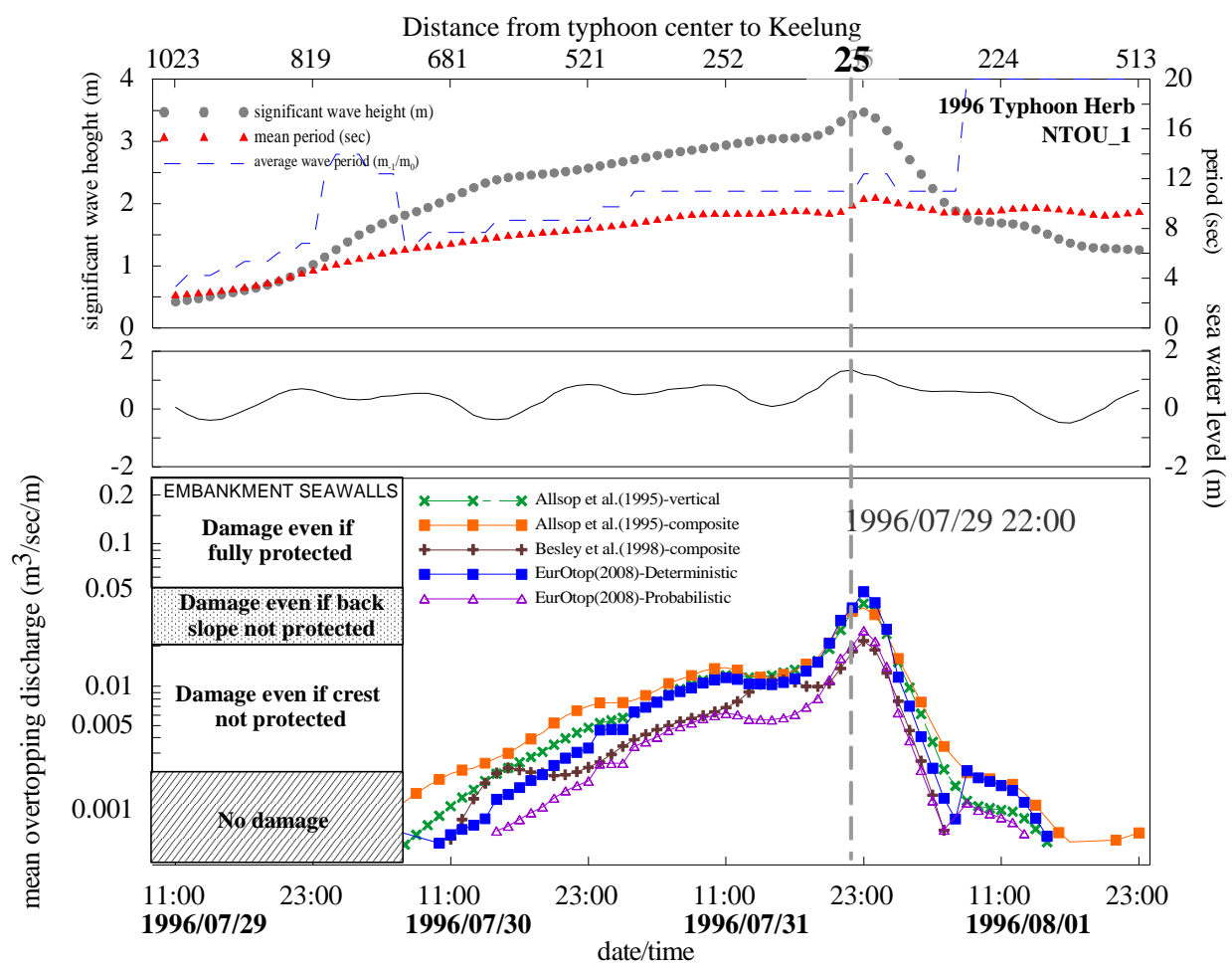

(a)NTOU 1

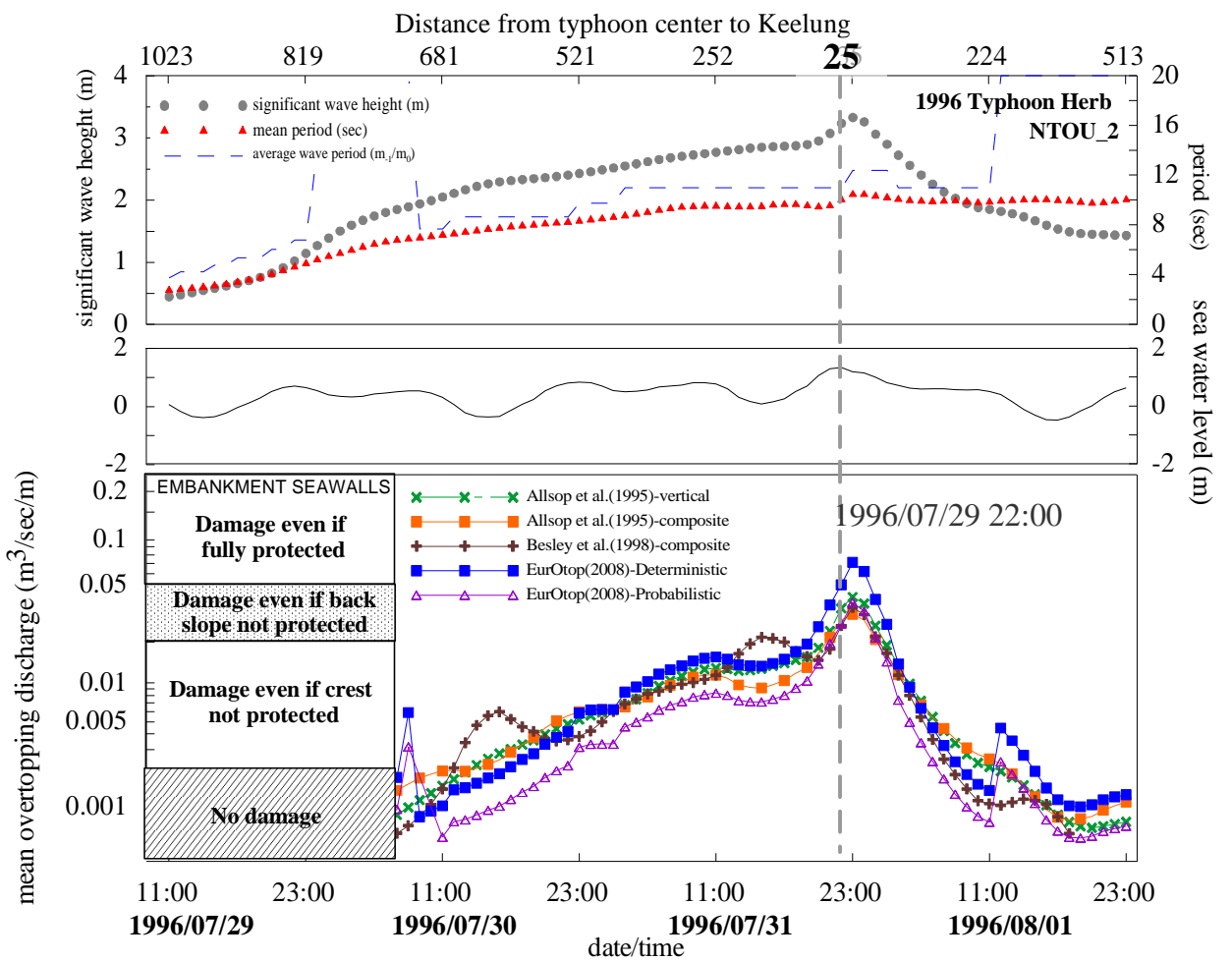

(b) NTOU 2

Figure 7. The calculated overtopping discharges at two sites during Typhoon Herb (1996). 


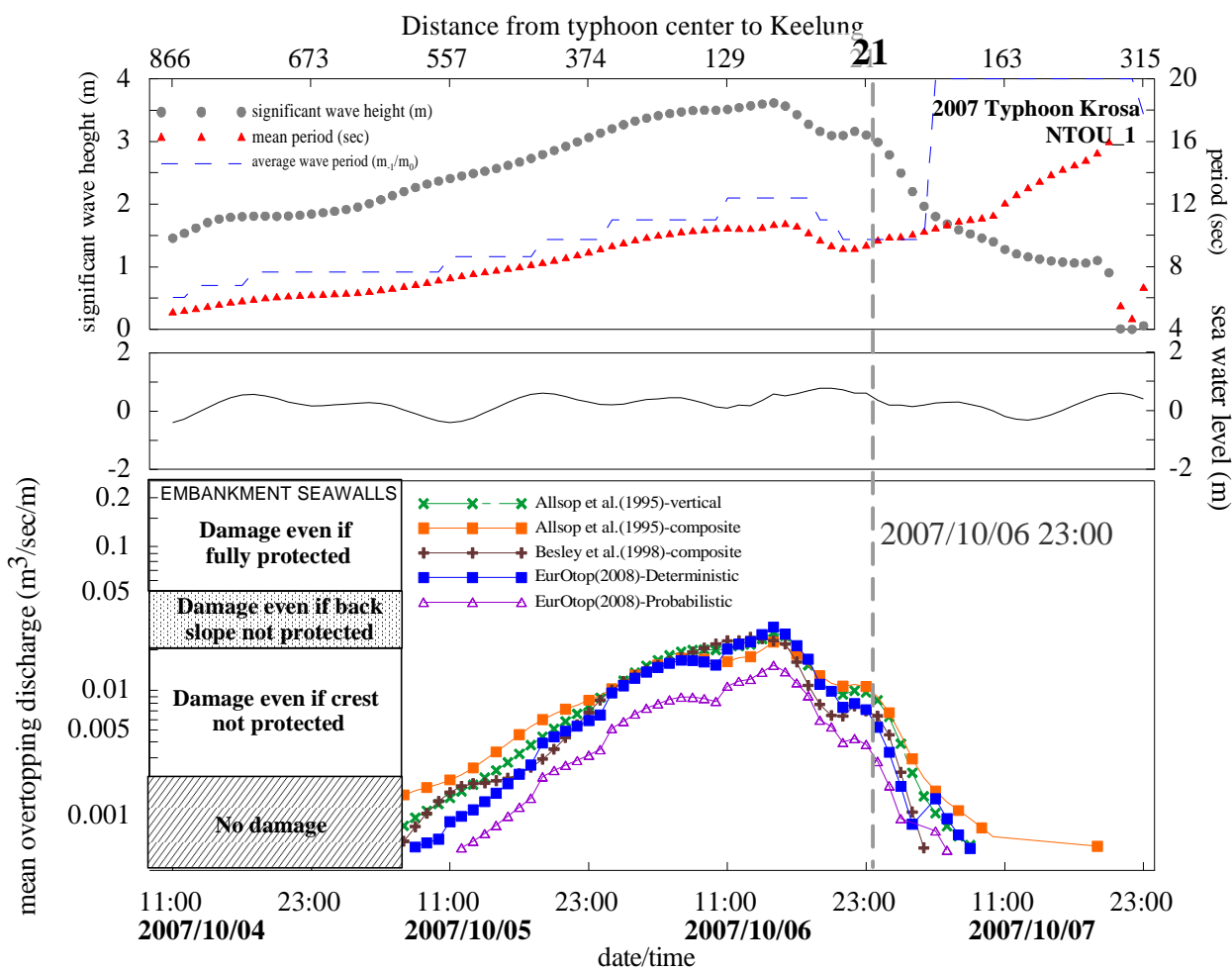

(a) NTOU 1

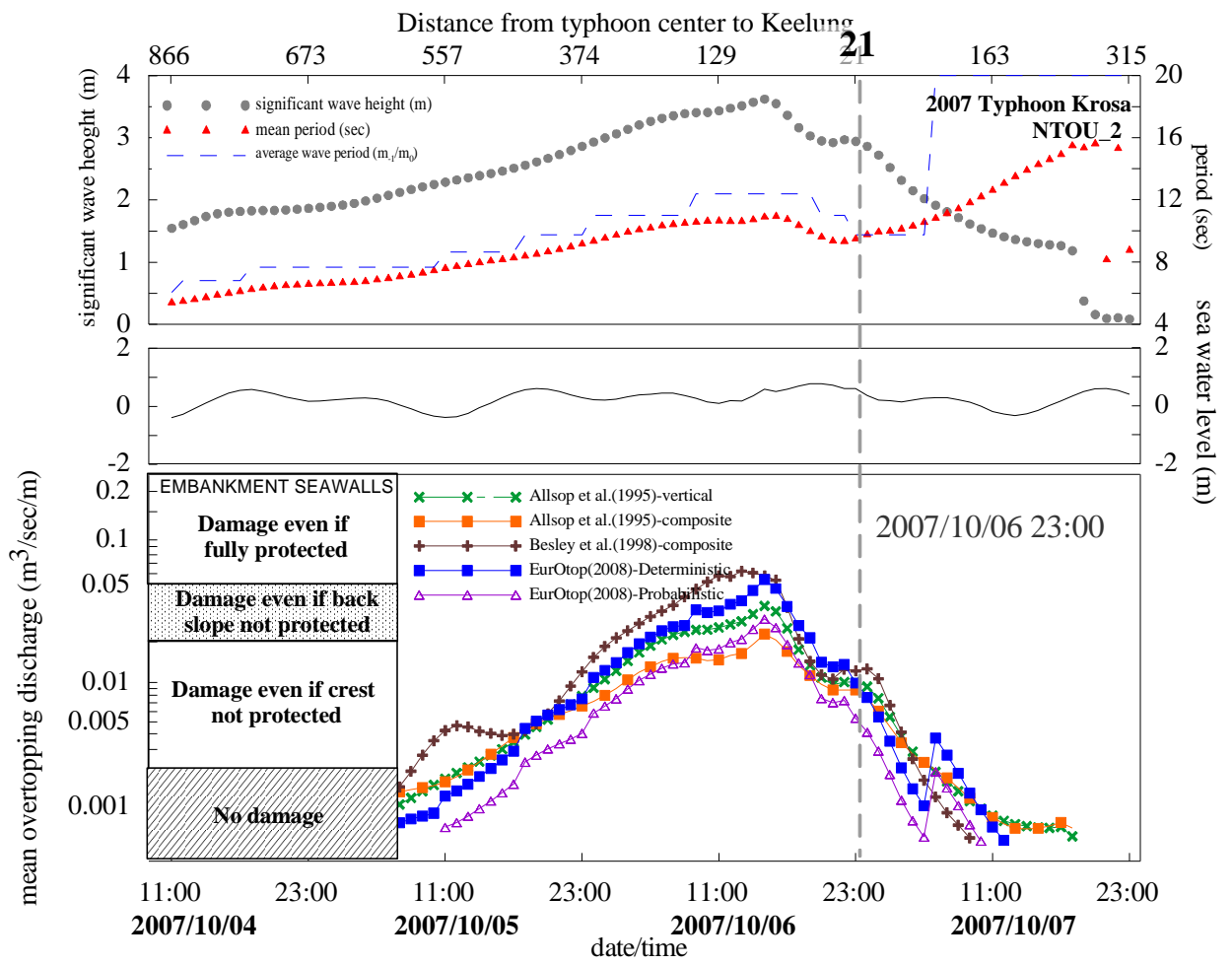

(b) NTOU 2

Figure 8. The calculated overtopping discharges at two sites during Typhoon Krosa (2007). 
The peak values of predicted overtopping discharges at two sites are 0.048 (NTOU 1) and $0.071 \mathrm{~m}^{3} / \mathrm{s} / \mathrm{m}$ (NTOU 2) during Typhoon Herb, and they have occurred at almost the same time as typhoon's center closed. But the peak predictions during Typhoon Krosa are 0.029 (NTOU 1) and $0.062 \mathrm{~m}^{3} / \mathrm{s} / \mathrm{m}$ (NTOU 2) when the typhoon stationed offshore eastern Taiwan. Later, the second peak values are 0.011 (NTOU 1) and $0.014 \mathrm{~m}^{3} / \mathrm{s} / \mathrm{m}$ (NTOU 2) when the typhoon continued and approached Keelung. The results show that the water depths of NTOU 2 are shallower than that of NTOU 1 while the discharges at NTOU 1 are larger than those at NTOU 2.

The results in different sites show that the calculations with Allsop's (1995) and Besley's (1998) at NTOU 1 are larger than those at NTOU 2, the calculations with probabilistic method are lowest during Typhoon Krosa. Moreover, the results in different formulae show that the calculations by Allsop's vertical formula are larger than others in addition to the results with deterministic method. The calculations with Allsop's composite formula at NTOU 1 are larger than those with Besley, but the calculations at NTOU 2 with Besley's are larger than those with Allsop's.

According to Tsai et al. (2006), the old seawalls had suffered rupture of parapets and losing of backfill soils and the resulting flooding on campus due to Typhoon Herb. Thus by comparing with the lowest criteria for damages on unprotected slope, i.e. $0.02 \mathrm{~m}^{3} / \mathrm{s} / \mathrm{m}$, it is confirmed that all maximum predictions during Typhoon Herb have exceeded the criterion for both structure types at both sites. On the other hand, most of the predictions during Typhoon Krosa are seen to be lower than the criterion In fact, only the old seawall has suffered superstructure damages but they were not seen to happen again on the rebuilt seawall during Typhoon Krosa. This simply implies that the rebuilt seawall could effectively defend wave impacts on the parapet of seawalls.

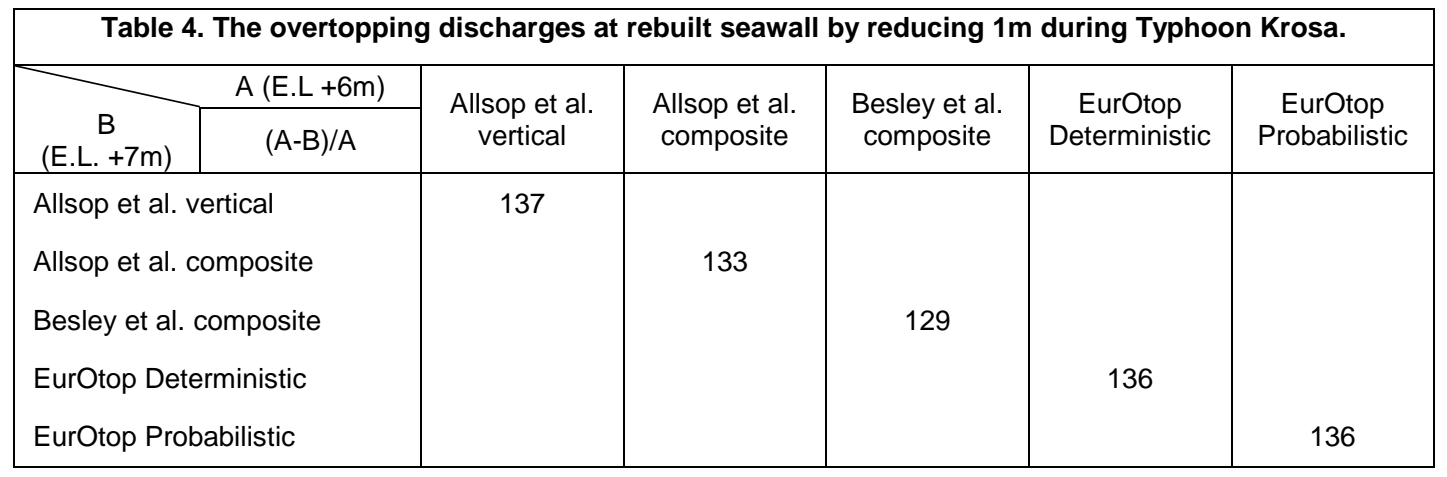

It is particularly illustrated In Table 4 that as the crest level of the rebuilt seawall decrease by $1 \mathrm{~m}$, most of the calculated average discharges have increased 29 37\%. Hence, the rebuilt seawall has played an effective role on reducing the overtopping discharges by lifting up the crest by only $1 \mathrm{~m}$ during Typhoon Krosa. By comparing the maximum discharges with the deterministic method of EurOtop manual during Typhoon Krosa with the same crest level of E.L. $+6 m$, the peak overtopping discharges increase to be 0.045 (NTOU 1) and 0.085 (NTOU 2) $\mathrm{m}^{3} / \mathrm{s} / \mathrm{m}$, respectively. The maximum discharge at NTOU 2 during Typhoon Krosa is even larger than that during Typhoon Herb. This further confirms the effect of higher crest elevation on reducing wave overtopping.

\section{CONCLUDING REMARKS}

In this study, the overtopping discharges at NTOU seawalls by the two typhoons with similar paths, strength, and wave conditions but causing different seawall damages are estimated with existing empirical formulae including those of EurOtop manual. On aplying the EurOtop formulae, calculations of overtopping discharges adopt the average wave period $\left(T_{m-1,0}\right)$. The results show that the peak overtopping discharges during Typhoon Herb (1996) are larger than those during Typhoon Krosa (2007) at the two selected sites. In addition, the water depth at toe of eastern NTOU seawalls (NTOU 2) are shallower than that at northern NTOU seawall (NTOU 1) resulting in larger discharges at NTOU 1 than those at NTOU 2. The calculations show that the peak wave 
overtopping discharges during Typhoon Herb are all greater than the criteria for damages on back slope of seawalls. This agrees well with the NTOU seawall failure event during Typhoon Herb. The predicted failure does not again happen to NTOU seawall during Typhoon Krosa implying the effective reduction in overtopping discharges by lifting up $1 \mathrm{~m}$ of the crest through rebuilding the previously damaged seawall. So far, the complex physical mechanism due to interactions of fluid-structure is yet to be explored with further studies.

\section{REFERENCES}

Allsop, N.W.H., Besley, P. and Madurini, L., 1995. Overtopping performance of vertical and composite breakwaters, seawalls and low reflection alternatives, Final Proceedings MCS Project Workshop, Alderney, United Kingdom.

Besley, P., Stewart, T. and Allsop, N.W.H., 1998. Overtopping of vertical structures: new prediction methods to account for shallow water conditions, Proc. Conf. Coastlines, Structures and Breakwaters, Institution of Civil Engineers, Thomas Telford, London, 45-57.

Bruce, T., Allsop, N.W.H. and Pearson, J., 2001. Violent overtopping of seawalls- extended prediction methods, Proc Conf Coastlines, Structures and Breakwaters, Institution of Civil Engineers, Thomas Telford, London, 245-255.

Engineering, A.C.o., 2002. Coastal Engineering Manual. Department of the Army, Waterways Experiment Station, Army Corps of Engineers, Vicksburg, Mississippi.

EurOtop 2007. EurOtop - Wave Overtopping of Sea Defences and Related Structures: Assessment Manual, Environment Agency (UK), Expertise Netwerk Waterkeren (NL), Kuratorium fr Forschung im Ksteningenieurwesen (DE), Pullen, T., Allsop, N.W.H., Bruce, T., Kortenhaus, A., Schüttrumpf, H. and van der Meer, J.W.; http://www.overtopping-manual.com.

Franco, C. and Franco, L., 1999. Overtopping formulas for caisson breakwaters with nonbreaking 3D waves. Journal of Waterway Port Coastal and Ocean Engineering-Asce, 125, 2, 98-108.

Franco, L., de Gerloni, M. and van der Meer, J.W., 1995. Wave overtopping on vertical and composite breakwaters. Proceedings of the Coastal Engineering Conference. ASCE, Kobe, Jpn, pp. 10301044.

Goda, Y., 1985. Random Seas and Design of Maritime Structures. University of Tokyo Press, Tokyo.

Tsai, C.H., S.Y. Tzang, S.S. Hsiao, C.C. Cheng and H.W. Li, 2006. Coastal structure failures and coastal waves on the north coast of Taiwan due to typhoon Herb, Journal of Coastal Research, 22, 2, 393-405.

Tzang, S. Y. and S. S. Hsiao, 1999. A case study on typhoon-induced consecutive damages on coastal structures at Keelung Coast. Coastal Structures' 99, ASCE, Santander, Spain, 1017-1025.

Tzang, S. Y., Lin, J.G., Hsiao, S.S., 2008. Comparisons of Coastal Structure Failures Due to Typhoon Krosa and Herb in Coastal Waters nearby NTOU. Proceeding of 30th Conference on Ocean Engineering, pp.463-468. (in Chinese)

Tzang, S.Y., Ou, S.H., Chen, D.W. and Ho, C.C., 2009. Investigations of Wave Overtopping over Vertical Seawalls by Typhoon Herb (1996) on Northeastern Coast of Taiwan, Proceeding of 5th International Conference on Asian and Pacific Coasts (APAC2009), Singapore, 4, 44-50. 